
\title{
25 Research Square \\ Spatial and physicochemical assessment of groundwater quality index in the urban coastal region of Sri Lanka
}

TANT Perera ( $\square$ nilusha@et.cmb.ac.lk )

University of Colombo https://orcid.org/0000-0001-9867-2056

HMMSD Herath

University of Colombo

Ranjana U.K Piyadasa

University of Colombo

Liu Jianhui

Ministry of Natural Resources of the People's Republic of China

Li Bing

Ministry of Natural Resources of the People's Republic of China

\section{Research Article}

Keywords: GIS modelling, potable water, WQI, water quality standards

Posted Date: June 18th, 2021

DOI: https://doi.org/10.21203/rs.3.rs-634457/v1

License: (c) (1) This work is licensed under a Creative Commons Attribution 4.0 International License. Read Full License

Version of Record: A version of this preprint was published at Environmental Science and Pollution Research on October 14th, 2021. See the published version at https://doi.org/10.1007/s11356-02116911-x. 


\section{Abstract}

This study used the groundwater quality index (GWQI) and Geographic Information System (GIS) techniques to examine groundwater quality in the western coastal region of Sri Lanka. The spatial and temporal variation of 18 groundwater samples' physiochemical parameters [pH, electrical conductivity (EC), turbidity, total dissolved solids (TDS), sodium $\left(\mathrm{Na}^{+}\right)$, potassium $\left(\mathrm{K}^{+}\right)$, calcium $\left(\mathrm{Ca}^{2+}\right)$, magnesium $\left(\mathrm{Mg}^{2+}\right)$, chloride $\left(\mathrm{Cl}^{-}\right)$, and bicarbonate $\left(\mathrm{HCO}_{3}{ }^{-}\right)$] were studied. According to the WHO and $\mathrm{SLS}, 11 \%$ of samples had EC levels that were above the acceptable range, and $22 \%$ had turbidity levels that were beyond the acceptable range. When considering, $\mathrm{pH}$, TDS, other cations, and anions analyzed in the study were still below the standard permissible levels. The western coastline region, as well as several areas of the central study region, had significant concentrations of physicochemical parameters. According to the GWQI, water was consumable in $77.78 \%$ of locations in the study region and unsatisfactory in $22.22 \%$. Furthermore, due to severe coastal erosion, the quality of groundwater in the study region is deteriorating, therefore maintaining a comprehensive groundwater management strategy to promote sustainable water consumption is imperative.

\section{Introduction}

Groundwater pollution has a significant impact on the environment and human existence today, as it is the primary source of water (Farzaneh et al. 2021; Khanoranga \& Khalid 2019; Yang et al. 2016). Agriculture, domestic consumption, industrial activity, and other activities all depend on groundwater (Mukherjee \& Singh 2018; Tiwari et al. 2017). Excessive irrigation, excessive use of agricultural inputs, sanitary landfills, climate change, and population growth are all putting strain on groundwater resources (UN 2019). Groundwater, on the other hand, meets the needs of two-thirds of the world's population through their water-dependent activities (Adimalla \& Li 2019).

To address the issue of water scarcity and management, the United Nations (UN) has made priorities to achieve clean drinking water for everyone in their Millennium Development Goals and in the Agenda 30 by 2030 (WHO 2017). As a result, to combat ground water pollution, more consideration should be given, as many countries are currently experiencing a scarcity of fresh water resources (Pant 2011; UNEP 2018). In several regions of Sri Lanka, specifically in the Maha Oya river basin, there is a high amount of contamination. $74 \%$ of inhabitants in the western coastal region utilize their land for residential and industrial purposes (tourism, hotels, and restaurants), whereas $24 \%$ use their lands for agricultural production. Water contamination in the Western coastal region is induced by nutrient and toxic inputs from agricultural, as well as urban and industrial development. In the Maha Oya basin, untreated domestic water is usually released into rivers (Hayzoun et al. 2015). In light of these many issues, policymakers and decision-makers depend heavily on WQI to estimate the efficiency of a water source while also determining the usefulness of initiatives and activities aimed at improving groundwater quality. The Water Quality Index can be used to determine the quality of water (Jain et al. 2010; Nihalani \& Meeruty 2020). 
By aggregating and evaluating various criteria using a single mathematical classification scheme, this method can be used to evaluate water quality and facilitate in decision-making (De La Mora-Orozco et al. 2017). The WQI is calculated by combining physicochemical and biological properties of water (Gitau et al. 2016; Vaiphei et al. 2020). The Water Quality Index (WQI) is an important indicator for determining the extent of contamination in water (Singh et al. 2019; Tian et al. 2019; Wang \& Zhang 2018). Water monitoring can be used to determine the amount of pollutants present in a pool of water. As a result, the results of water quality monitoring can be employed to evaluate the status of bodies of water (Chathuranga et al. 2018).

In some regions, water quality characteristics in groundwater can be used to calculate the ground water quality index. Excess concentrations of these parameters $\left(\mathrm{NO}_{3}{ }^{-}, \mathrm{PO}_{4}{ }^{3-}\right.$, etc.) in water can cause serious health problems, whereas some other parameters in excess quantities do not affect but do impair the appetite (Sadat-Noori et al. 2013). In recent years, a great percentage of groundwater contamination and intrusion studies have primarily been carried out in various parts of Sri Lanka (Herath \& Ratnayake 2007; IGES 2007; International Water Management Project 2005) and have used a variety of approaches to realize groundwater contamination and identify the cause (Villholth \& Rajasooriyar 2010).

Seawater intrusion and nitrate contamination of groundwater are quite common along the Jaffna peninsula of Sri Lanka, according to Herath et al. (2017) and Thushyanthy et al. (2010). Furthermore, the area's ground water quality measurements were above the SLS permissible range. Mikunthan and De Silva (2008) used geostatistical approaches to assess groundwater quality in the Thirunelvely and Kondavil areas. They concluded that positive management strategies including soil conservation and fertilizer reduction ( $\mathrm{N}$-top dressing) had a substantial impact on high ground water chemistry. According to a study conducted by Cooray et al. (2019), all water sources in the dry zone of Sri Lanka required further treatment before consumption, with the exception of $6.4 \%$ samples.

The Geographic Information System (GIS) has risen to prominence as the most popular tool for gathering, classifying, and displaying spatial data, as well as for using the data to make decisions, in many domains, including geographical and geo-environmental disciplines (Eltarabily \& Moghazy 2021; Gunaalan et al. 2018; Rajasooriyar et al. 2013). However, a precise physicochemical description of groundwater content has yet to be determined in Sri Lanka's western coastline region. As a result, the study's main goals are to (a) use a Geographic Information System (GIS) to create a spatial distribution map of various physicochemical parameters, (b) locate suitable and unsuitable groundwater quality zones for drinking, and (c) evaluate groundwater quality by developing a groundwater quality index (GWQI). The findings of this study may be useful to decision-makers and the scientific community in determining the best course of action for groundwater quality conservation.

\section{Methodology}

\subsection{Study area}


The targeted case study region (Waikkala $-7.2838^{\circ} \mathrm{N}, 79.8578^{\circ} \mathrm{E}-$ Fig. 1 ) is situated in the Puttlam District of Sri Lanka's North Western Province. It covers 3,072 square kilometers. To the north, the Kala Oya and Modaragam Aru, to the east, the Anuradhapura District and Kurunegala District, to the south, the Ma Oya, and to the west, the Indian Ocean.

From the Maha Oya River Mouth left bank, which is the southern boundary of Puttlam District, to the northwards, the study region encompasses a $24 \mathrm{~km}^{2}$ area. The mouth of the Gin Ganga River is also included in the case study area. This region, which is part of the Wennappuwa Divisional Secretariat Division, comprises 28 Grama Niladhari Divisions. According to the 2012 census statistics from the Department of Census and Statistics, the population density distribution of this area is $1746 \mathrm{~km}^{2}$. The alluvial deposits and ferruginous gravels, as well as the unconsolidated sands and spits of the coastal region, retain groundwater. The most prevalent groundwater abstraction technologies are dug wells, dugcum bore wells, and bore wells, and their yields are mostly governed by the recharge conditions in the region. The annual average rainfall in the district is $1174 \mathrm{~mm}$, with November being the wettest month of the year. Puttalam, which is located on the seashore, is mostly flat, though the land rises to approximately 60 meters inland. There are regions of reddish brown earth and low humic gley soils inland, and the soils are mostly red-yellow latosols.

\subsection{Groundwater sample collection and chemical analysis}

Groundwater samples were gathered at 18 locations between January 2019 and January 2020, from a drilled well that had previously been dug or a deep bore hole that had previously been drilled. The groundwater samples were taken according to APHA guidelines (APHA 2012) (Table 1). The water samples were collected in pre-cleaned $1 \mathrm{~L}$ high-density polythene sample vials. The samples were tagged and delivered to a chemical laboratory, where they were physicochemically evaluated under $4^{\circ} \mathrm{C}$ conditions (Jehan et al. 2020).

Using Arc GIS 10.2 software, the case study region will be partitioned into a 9 « 5 grid. A GPS position at the mid-point of selected spots for water quality monitoring method has been navigated in each cell of the grid in the study region. A handheld optical pH/EC/TDS meter (Hanna HI 9811-5) was used to determine physico-chemical parameters such as electrical conductivity (EC), hydrogen ion concentration $(\mathrm{pH})$, and total dissolved solids (TDS) in the field. The basic protocols of the American Public Health Association were used to examine other chemical parameters (APHA 2012). The $\mathrm{AgNO}_{3}$ titration was used to determine the chloride $\left(\mathrm{Cl}^{-}\right)$concentration. The magnesium $\left(\mathrm{Mg}^{2+}\right)$ was calculated using equations 1 and 2 (Adimalla \& Taloor 2020).

Magnesium Hardness $=$ Total Hardness - Calcium Hardness Eq. 1

$\mathrm{Mg}^{2+}(\mathrm{mg} / \mathrm{L})=\mathrm{MgH}$ « equivalent weight of $\mathrm{Mg}^{2+}$ « Normality of EDTA ................... Eq. 2

Table 1 Methods used for chemical analysis of groundwater samples along with their relative weights, used in the computation of groundwater quality 


\begin{tabular}{|c|c|c|c|c|c|}
\hline Parameters & Units & Analytical method & Reagent & $\begin{array}{l}\text { Weigh } \\
\text { t } w i\end{array}$ & $\begin{array}{l}\text { Relative } \\
\text { weight (Wi): } \\
W i=\frac{w i}{\sum_{i}^{n} w i}\end{array}$ \\
\hline $\mathrm{pH}$ & & $\begin{array}{l}\text { PH/EC/TDS meter (Eutech"s } \\
\text { Cyber Scan CD650 waterproof } \\
\text { handheld multipara meter) } \\
\text { (APHA 2012). }\end{array}$ & $\mathrm{pH} 4,7$ and 10 & 3 & 0.11 \\
\hline EC & $\mu \mathrm{S} / \mathrm{cm}$ & PH/EC/TDS meter (APHA 2012). & $\mathrm{KCl}$ & 3 & 0.11 \\
\hline TDS & $\mathrm{Mg} / \mathrm{L}$ & PH/EC/TDS meter (APHA 2012). & $\mathrm{KCl}$ & 5 & 0.18 \\
\hline $\mathrm{Cl}^{-}$ & $\mathrm{Mg} / \mathrm{L}$ & Titrimetric method (APHA 2012). & $\begin{array}{l}\text { Silver nitrate }\left(\mathrm{AgNO}_{3}\right) \text {, } \\
\text { and potassium chromate } \\
\left(\mathrm{K}_{2} \mathrm{CrO}_{4}\right)\end{array}$ & 4 & 0.14 \\
\hline $\mathrm{Mg}^{2+}$ & $\mathrm{Mg} / \mathrm{L}$ & Titrimetric method (APHA 2012). & $\begin{array}{l}\text { EDTA, sodium } \\
\text { hydroxide and murexide }\end{array}$ & 3 & 0.11 \\
\hline $\mathrm{Ca}^{2+}$ & $\mathrm{Mg} / \mathrm{L}$ & Titrimetric method (APHA 2012). & $\begin{array}{l}\text { EDTA, Sodium } \\
\text { hydroxide and murexide }\end{array}$ & 3 & 0.11 \\
\hline $\mathrm{K}^{+}$ & $\mathrm{Mg} / \mathrm{L}$ & Flame photometric (APHA 2012). & $\mathrm{NaCl}$ and $\mathrm{KCl}$ & 1 & 0.04 \\
\hline $\mathrm{Na}^{+}$ & $\mathrm{Mg} / \mathrm{L}$ & Flame photometric (APHA 2012). & $\mathrm{NaCl}$ and $\mathrm{KCl}$ & 2 & 0.07 \\
\hline $\mathrm{HCO}_{3}{ }^{2-}$ & $\mathrm{Mg} / \mathrm{L}$ & Titrimetric method (APHA 2012). & $\begin{array}{l}\text { Hydrosulfuric acid } \\
\left(\mathrm{H}_{2} \mathrm{SO}_{4}\right) \text {, Methyl } \\
\text { Orange indicator }\end{array}$ & 2 & 0.07 \\
\hline Turbidity & NTU & $\begin{array}{l}\text { EUTECH waterproof Cyber scan } \\
\text { pH650 handheld meter kit (APHA } \\
\text { 2012). }\end{array}$ & Formazin suspensions & 2 & 0.07 \\
\hline
\end{tabular}

\subsection{Spatial distribution maps}

The exact sampling locations were marked using a portable Global Positioning System (GPS, Garman eTrex 30), and the geographical coordinates were imported into a Geographic Information System (GIS) program. The spatiotemporal behavior analysis and geographic distribution map of groundwater quality were accomplished using the spatial observer model of ArcGIS version 10.1 (Şener et al. 2021).

\subsection{Groundwater quality index (GWQI)}

The ground water quality index (GWQI) was developed using the collected data to assess the water's acceptability for drinking (Adimalla et al. 2018; Chathuranga et al. 2018; Ramakrishnaiah et al. 2009; Rabeiy 2018). The first stage in the GWQI classification process was to assign weights (wi) to each parameter and then calculate relative weight (Wi) (Eq. 3). Based on expert opinions gathered from various previous studies, a minimum weight of one (1) has been assigned to parameters such as $\mathrm{Na}^{+}$and $\mathrm{K}^{+}$ because they are less important in groundwater quality evaluation (Rajmohan 2021), and a maximum 
weight of five (5) has been assigned to parameters which are more pertinent in groundwater quality evaluation such as TDS (Table 1).

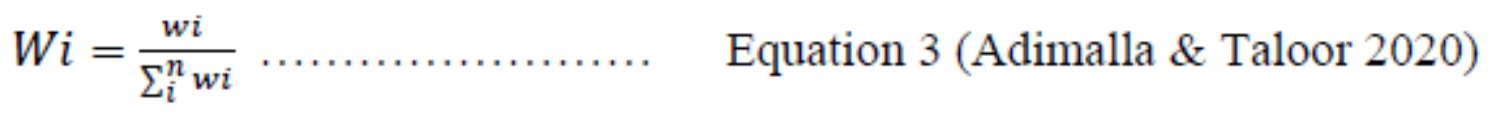

According to WHO guidelines, each parameter's consistency rating scale (Qi) is calculated by multiplying its concentration in each water sample by its corresponding standard and then multiplying by 100 (Eq. 4).

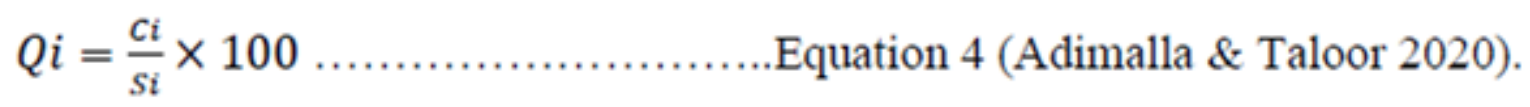

Where ci is the concentration of each criterion of groundwater quality, Qi is the quality rating, and $\mathrm{Si}$ is the chemical parameter's recommended guideline value. Using equations 5 and 6 , the Sub-index (Sli) and GWQI were determined.

$S / i=W i \ll Q i$ Eq. 5 (Adimalla \& Taloor 2020)

$G W Q I=\sum_{i=0}^{n} S I i$

Equation 6 (Adimalla \& Taloor 2020).

\section{Results And Discussion}

\subsection{Physicochemical parameters of the ground water}

The significance of groundwater resource quality is critical since it is a fundamental factor in determining its suitability for potable use in the studied area. The descriptive information for the various physicochemical properties of groundwater samples is shown in Table 2. The data were also compared to WHO (2017) and SLS Guidelines to see if they were suitable for drinking in the study location. 
Table 2

Descriptive statistics of sub-indices of water quality parameters.

\begin{tabular}{|llllllll|}
\hline Parameters & Unit & Min & Max & Mean & SD & SLS & WHO \\
\hline $\mathrm{pH}$ & $\mathrm{mg} / \mathrm{L}$ & 6.21 & 7.68 & 6.93 & 0.37 & $6.5-9.0$ & $6.5-8.5$ \\
\hline $\mathrm{EC}$ & $\mu \mathrm{S} / \mathrm{cm}$ & 430.10 & 99144.72 & 10709.76 & 28948.70 & 750 & 1500 \\
\hline $\mathrm{TDS}$ & $\mathrm{mg} / \mathrm{L}$ & 168.25 & 748.77 & 299.20 & 139.80 & 2000 & 1000 \\
\hline $\mathrm{Cl}-$ & $\mathrm{mg} / \mathrm{L}$ & 110.00 & 443.00 & 191.17 & 92.52 & 250 & 600 \\
\hline $\mathrm{Mg}^{2+}$ & $\mathrm{mg} / \mathrm{L}$ & 1.67 & 23.00 & 10.56 & 6.87 & 150 & 150 \\
\hline $\mathrm{Ca}^{2+}$ & $\mathrm{mg} / \mathrm{L}$ & 5.00 & 43.00 & 19.94 & 12.89 & 100 & 300 \\
\hline $\mathrm{Na}^{+}$ & $\mathrm{mg} / \mathrm{L}$ & 22 & 173 & 60.76 & 35.08 & 200 & 200 \\
\hline $\mathrm{K}^{+}$ & $\mathrm{mg} / \mathrm{L}$ & 2.00 & 24.67 & 12.52 & 6.53 & - & - \\
\hline $\mathrm{HCO}_{3}{ }^{-}$ & $\mathrm{mg} / \mathrm{L}$ & 26 & 54 & 37.11 & 8.25 & - & 350 \\
\hline Turbidity $^{+}$ & $\mathrm{NTU}$ & 0.62 & 41.67 & 5.38 & 9.44 & $2-8$ & 5 \\
\hline 1
\end{tabular}

\subsubsection{Hydrogen ion concentration $(\mathrm{pH})$}

$\mathrm{pH}$ measures the acidity and alkalinity of groundwater. Despite the fact that $\mathrm{pH}$ has no direct impact on human health, it is one of the most important water quality parameters. According to WHO guidelines, a suitable $\mathrm{pH}$ range of 6.5 to 8.5 is recommended (WHO 2017). The groundwater samples were acidic to alkaline in nature, with a $\mathrm{pH}$ ranging from 6.21 to 7.68 , with an average of 6.93 , according to the study's findings (Table 2). The $\mathrm{pH}$ range for groundwater in Sri Lanka was 6.50-9.00, with a maximum permissible level of 9.00. However, no location was found to be above the maximum permitted limit in any of the groundwater tests (Table 2). According to Sampath et al. (2011), the $\mathrm{pH}$ range of ground water in Sri Lanka's Puttlam district was 6.30-8.20. In addition, Young et al. (2011) detected a pH range of 5.76 to 8.70 in Sri Lanka's north-western province. The pH variation in ground water in Sri Lanka's western province was below the SLS permitted level (4.0 to 8.2) and was not hazardous for drinking (Premalal \& Jayewardene 2015). Figure $2 \mathrm{a}$ depicts the geographic distribution of $\mathrm{pH}$ in the research area.

\subsubsection{Electrical conductivity (EC)}

According to (Kanga et al. 2020), the ionic concentration of groundwater is commonly measured by calculating the EC, which varies depending on the concentration, type of ions present in the water, and temperature. The EC in the research area's groundwater ranged from 430.10 to $99144.72 \mathrm{~S} / \mathrm{cm}$, with an average of $10709.76 \mathrm{~S} / \mathrm{cm}$ (Table 2). According to WHO drinking water recommendations, the maximum permitted EC concentration in water is $1500 \mathrm{~S} / \mathrm{cm}$ (WHO 2017). The maximum allowed level of groundwater in Sri Lanka is $750 \mathrm{~S} / \mathrm{cm}$. Only $11 \%$ of groundwater samples were found to be above the permitted level (Table 2). Figure $2 \mathrm{~b}$ depicts the geographic distribution of EC in the research area. 
According to a study conducted by Sampath et al. (2011), EC levels were greater than the acceptable values of WHO drinking water quality guidelines in $76 \%$ of areas in the Puttlam area of Sri Lanka. Another study in Sri Lanka's Puttlam area found that the maximum permitted amount of EC has been exceeded by the WHO and SLS (Arasaretnam et al. 2018; Edirisinghe et al. 2016; Matharaarachchi et al. 2014; Subba Rao et al. 2012).

Furthermore, Young et al. (2011) found that EC in the north-western province ranged from 143 to 3549 $\mathrm{S} / \mathrm{cm}$. Gopalakrishnan et al. (2020) discovered that ground water in the Jaffna peninsula of Sri Lanka had a high salinity $(E C=20000 \mathrm{~S} / \mathrm{cm})$. As a result, salinization may have an impact on groundwater quality in the research area in the coming next few years.

\subsubsection{Total dissolved solids (TDS)}

TDS stands for Total Dissolved Solids, which refers to the numerous minerals that are present in dissolved form in water (Narsimha \& Sudarshan 2017). The principal dissolved solids in water are large carbonates, bicarbonates, sulfates, chlorides, silica, phosphates, sodium, potassium, calcium, and magnesium (Adimalla \& Venkatayogi 2018; Gnanachandrasamy et al. 2015). As a result, it's an important consideration for evaluating the consistency of drinking water and other forms of water. TDS content fluctuates between 168 and $749 \mathrm{mg} / \mathrm{L}$, with a mean value of $299 \mathrm{mg} / \mathrm{L}$, according to our research. All of the groundwater samples had TDS levels below the WHO (2017) limit (1000 mg/L) and SLS levels below the WHO (2017) threshold (2000 mg/L). According to previous studies, TDS concentrations in the Puttlam district of Sri Lanka are below the ideal threshold in $80 \%$ of the locations and $20 \%$ of the sites surpass the ideal level. Furthermore, TDS concentrations in all areas were of sufficient quality for drinking (Sampath et al. 2011; Wickramasinghe et al. 2021).According to Adimalla \& Taloor (2020), almost 95\% of the total samples were below the ideal threshold for drinking (TDS: $1000 \mathrm{mg} / \mathrm{L}$ ), while the remaining samples were suitable for irrigation (TDS: $1000-3000 \mathrm{mg} / \mathrm{L}$ ). The geographic distribution map of TDS is depicted in Figure 2c.

\subsubsection{Magnesium $\left(\mathrm{Mg}^{2+}\right)$ and calcium $\left(\mathrm{Ca}^{2+}\right)$}

According to WHO (2017) standards, the maximum permissible $\mathrm{Mg}^{2+}$ concentration is $150 \mathrm{mg} / \mathrm{L}$. Groundwater $\mathrm{Mg}^{2+}$ values in the study region varied from 1.6 to $23 \mathrm{mg} / \mathrm{L}$, with an average of $10.5 \mathrm{mg} / \mathrm{L}$. (See Table 2) The concentration of $\mathrm{Mg}^{2+}$ in the sample region's groundwater was determined to be below the WHO (2017) or SLS-recommended maximum permissible level. The north and south-western regions of the sample area had higher concentrations (Fig. 3b). According to the study's findings, the $\mathrm{Ca}^{2+}$ concentration in groundwater in the research area ranged from 5 to $43 \mathrm{mg} / \mathrm{L}$, with an average of 20 $\mathrm{mg} / \mathrm{L}$. (Fig. 3c). Furthermore, all of the samples fall well within the established parameters (WHO 2017). According to Young et al. (2011), $\mathrm{Mg}^{2+}$ and $\mathrm{Ca}^{2+}$ concentrations in Sri Lanka's north-western province ranged from 4.98 to $112 \mathrm{mg} / \mathrm{L}$ and 1.29 to $98 \mathrm{mg} / \mathrm{L}$, respectively. Carbonate minerals dissolving caused comparatively high quantities of $\mathrm{Mg}^{2+}$ and $\mathrm{Ca}^{2+}$ in various sections of the northwestern province. According to Sampath et al. (2011), total hardness $\left(\mathrm{Ca}^{2+}\right.$ and $\left.\mathrm{Mg}^{2+}\right)$ in Puttlam district water surpasses the ideal level, with only $16 \%$ of places having sufficient potable water. 


\subsubsection{Sodium ( $\left.\mathrm{Na}^{+}\right)$and potassium $\left(\mathrm{K}^{+}\right)$}

The geographic distributions of $\mathrm{Na}^{+}$and $\mathrm{K}^{+}$are depicted in Figures $4 \mathrm{a}$ and $4 \mathrm{~b}$, respectively. The research area's central and northern regions have higher $\mathrm{Na}^{+}$concentrations, while the northwestern and southeastern regions have higher $\mathrm{K}^{+}$concentrations. The content of $\mathrm{Na}+$ in groundwater, on the other hand, varied from 22 to $173 \mathrm{mg} / \mathrm{L}$, with a mean of $60 \mathrm{mg} / \mathrm{L}$. (Table 2). The findings revealed that none of the groundwater samples tested fulfilled the WHO and SLS criteria (WHO, 2006). The average $\mathrm{Na}^{+}$and $\mathrm{K}^{+}$ concentrations in the north-western province, according to Young et al. (2011), were $79.77 \mathrm{mg} / \mathrm{L}$ and 6.12 $\mathrm{mg} / \mathrm{L}$, respectively. $\mathrm{K}^{+}$is the most important nutrient for humans (Adimalla \& Venkatayogi 2018), and too much of it might cause constipation (Alam et al. 2012). $\mathrm{K}^{+}$concentrations in the sample area's groundwater range from 2 to $25 \mathrm{mg} / \mathrm{L}$, with an average of $12.52 \mathrm{mg} / \mathrm{L}$. (Table 2). However, WHO recommendations for $\mathrm{K}^{+}$have yet to be established because it occurs naturally in drinking water at quantities far below those considered harmful to human health (Sakram \& Adimalla 2018; WHO 2017).

\subsubsection{Bicarbonate $\left(\mathrm{HCO}_{3}{ }^{-}\right)$}

The $\mathrm{HCO}_{3}{ }^{-}$concentration in the sample area's groundwater ranges from 26 to $54 \mathrm{mg} / \mathrm{L}$, with a mean value of $37.11 \mathrm{mg} / \mathrm{L}$. (Table 2). Figure 5 a shows a geographic distribution map of $\mathrm{HCO}_{3}{ }^{-}$concentrations, which reveal that larger concentrations were found in the southern northern region of the sample region, while low concentrations were found in the northern part. According to Young et al. (2011), $\mathrm{HCO}_{3}{ }^{-}$ concentrations in the northwestern province ranged from 10 to $240 \mathrm{mg} / \mathrm{L}$, while Jayasena et al. (2008) found it to be between 3.5 and $966 \mathrm{mg} / \mathrm{L}$.

\subsubsection{Chloride ( $\left.\mathrm{Cl}^{-}\right)$}

Excessive $\mathrm{Cl}^{-}$concentrations in groundwater are considered to be a sign of contamination from a variety of sources, and they give water a salty taste (Marghade et al. 2012). The concentration of $\mathrm{Cl}^{-}$in the sample area varies between 110 and $443 \mathrm{mg} / \mathrm{L}$. However, the mean $\mathrm{Cl}^{-}$concentration in the groundwater samples studied (191 mg/L) is lower than the overall permitted value of $600 \mathrm{mg} / \mathrm{L}$ (Table 2) (WHO 2017). Figure $5 \mathrm{~b}$ depicted the geographic distribution map of $\mathrm{Cl}^{-}$. Previous investigations in Sri Lanka's coastal region have revealed desirable $\mathrm{Cl}^{-}$values (32-1100 mg/L) in accordance with the SLS (Mikunthan \& Silva 2010). Despite the fact that no health risks have been identified, people in coastal areas are unwilling to drink water due to texture and taste concerns.

\subsubsection{Turbidity}

Turbidity refers to the water's relative clarity, which inhibits light transmission. The turbidity of ground water in the research area ranged from 0.62 to $41.67 \mathrm{NTU}$ (Figure 5c). The maximum turbidity level was surpassed in $22 \%$ of locations, according to the SLS and WHO drinking water quality guidelines. As a result, it's unlikely to be suitable for drinking. Several earlier investigations have found that the turbidity in the groundwater of Puttlam district was much higher than the WHO and SLS permitted values.According 
to Galhenage et al. (2021), turbidity ranged from 1.6 to 164 NTU, while Gunarathna et al. (2021) found that turbidity ranged from 44 to 723 NTU. Furthermore, the study found that the mean turbidity in ground water was much higher than in surface water (Gunarathna et al. 2021).

\subsection{Groundwater quality index (GWQI)}

Table 3 shows the GWQI values calculated for each groundwater sample. Table 3 shows that GWQI values in groundwater in the research region ranged from 45.12 to 2700.55 , with an average of 337.78. Excellent water (WQI = 50), good water (WQI = 50 to 100), and poor water (WQI = 100 to 200), very poor water (WQI $=200$ to 300) and water unsuitable for drinking (WQI = >300) are some of the categories for GWQI (Ramakrishnaiah et al. 2009) (Fig. 6). Based on this classification, $16.67 \%$ of groundwater samples fall excellent, $61.11 \%$ and $11.11 \%$ fall under good and poor for drinking purpose categories in the study region (Fig. 7). NW6 and NW 14 were not suitable for drinking (11.11\%). 
Table 3

Results of groundwater quality index (GWQI) values in the study region.

\begin{tabular}{|lll|}
\hline Sample numbers & GWQI values & Type of water \\
\hline NW 1 & 51.79 & Good \\
\hline NW 2 & 52.69 & Good \\
\hline NW 3 & 82.49 & Good \\
\hline NW 4 & 49.30 & Excellent \\
\hline NW 5 & 2200.12 & Unsuitable \\
\hline NW 6 & 159.59 & Poor \\
\hline NW 7 & 70.81 & Good \\
\hline NW 8 & 132.69 & Poor \\
\hline NW 9 & 55.09 & Good \\
\hline NW 10 & 98.05 & Good \\
\hline NW 11 & 45.12 & Excellent \\
\hline NW 12 & 65.74 & Good \\
\hline NW 13 & 49.91 & Excellent \\
\hline NW 14 & 2700.55 & Unsuitable \\
\hline NW 15 & 54.54 & Good \\
\hline NW 16 & 70.39 & Good \\
\hline NW 17 & 62.87 & Good \\
\hline NW 18 & 78.25 & Good \\
\hline
\end{tabular}

\section{Conclusions}

The groundwater condition in the western coastal region of Sri Lanka begins to depreciate largely due to seawater intrusion and therefore, the water consumption has become uncertain. Hence, investigating water quality in the groundwater was crucial in the western coastal region in Sri Lanka. This study was used GIS to create a spatial distribution map of various physicochemical parameters and locate suitable and unsuitable groundwater quality zones for drinking and evaluated groundwater quality by developing a groundwater quality index (GWQI).

The groundwater in the research area is neutral to slightly alkaline in the composition according to the study. The most abundant cations and anions were $\mathrm{Na}^{+}$and $\mathrm{Cl}^{-}$, respectively. This could be owing to the 
region's coastal erosion and seawater intrusion. $\mathrm{Ca}^{2+}(5-43 \mathrm{mg} / \mathrm{L}), \mathrm{Na}^{+}(22-173 \mathrm{mg} / \mathrm{L})$, and $\mathrm{K}^{+}(2-$ $24.67 \mathrm{mg} / \mathrm{L}$ ) ions concentrations in the groundwater of the research region are within the maximum allowable limits when compared to $\mathrm{WHO}\left(\mathrm{Mg}^{2+} 300 \mathrm{mg} / \mathrm{L}, \mathrm{Na}^{+} 200 \mathrm{mg} / \mathrm{L}, \mathrm{K}^{+}\right.$Not recommended) drinking water quality guidelines and Sri Lankan water quality standards $\left(\mathrm{Ca}^{2+} 100 \mathrm{mg} / \mathrm{L}, \mathrm{Na}^{+} 200 \mathrm{mg} / \mathrm{L}, \mathrm{K}^{+} \mathrm{Not}\right.$ recommended). Excessive quantities of Turbidity (22\%) and EC (11\%) have also been discovered at a few groundwater sample sites in the research area. According to the GWQI, the groundwater quality in the study region ranges from excellent to poor for drinking. Turbidity and electrical conductivity had the greatest impact on groundwater quality index. The groundwater samples that are acceptable for drinking comprise $77.78 \%$ of the total, while the samples that are not appropriate for drinking constitute $22.22 \%$.

The research area's poor and unfit water for human consumption is mostly concentrated in the center and western coastal areas according to the spatial distribution maps. Therefore, to safeguard community well-being and safety, it is essential to make consistent monitoring valuation of seawater intrusion in the western coastal province of Sri Lanka.

\section{Declarations}

Ethics approval and consent to participate - Not applicable

Consent for publication - Not applicable

Availability of data and materials - Not applicable

Competing interests - The authors declare that they have no competing interests

Funding - Not applicable

\section{Authors' contributions}

T.A.N.T. Perera: Conceptualization, Data curation, Formal analysis, Methodology, Validation, Visualization, Writing - original draft, Writing - review \& editing.

HMMSD Herath: Conceptualization, Resources, Software, Validation, Visualization.

Ranjana UK Piyadasa: Conceptualization, Funding acquisition, Investigation, Project administration, Resources, Software, Supervision.

Liu Jianhui: Conceptualization, Investigation, Methodology, Resources, Supervision.

Li Bing: Conceptualization, Investigation, Methodology, Resources.

\section{References}


1. APHA (2012) Standard Methods for the Examination of Water and Wastewater, twenty-second ed. American Public Health Association, Washington, DC

2. Adimalla N, Taloor AK (2020) Hydrogeochemical investigation of groundwater quality in the hard rock terrain of South India using Geographic Information System (GIS) and groundwater quality index (GWQI) techniques. Groundwater for Sustainable Development 10(126):100288. https://doi.org/10.1016/j.gsd.2019.100288

3. Adimalla N, Li P (2019) Occurrence, health risks, and geochemical mechanisms of fluoride and nitrate in groundwater of the rock-dominant semi-arid region, Telangana State, India. Hum Ecol Risk Assess Int J 25 (1-2), 81-103. https://doi. org/10.1080/10807039.2018.148035

4. Adimalla N, Li P, Venkatayogi S (2018) Hydrogeochemical evaluation of groundwater quality for drinking and irrigation purposes and integrated interpretation with water quality index studies. Environ Process 5 (2), 363-383. https://doi.org/10.1007/ s40710-018-0297

5. Arasaretnam S, Prasadini HRP, Venujah K (2018) Assessment of Open well Water Quality around Puttalam District, Sri Lanka. International Journal of Advances in Scientific Research Engineering 4(12):225-232. https://doi.org/10.31695/ijasre.2018.33024

6. Bouderbala A (2017) Assessment of water quality index for the groundwater in the upper Cheliff plain, Algeria. J Geol Soc India 90, 347-356 (2017). https://doi.org/10.1007/s12594-017-0723-7

7. Chathuranga AGL, Perera TANT, De Silva PMCS, Jayasinghe GY (2018) Assessment of PhysicoChemical Parameters of Drinking Water Quality in Selected DS Divisions - Hambanthota District. 11th International Research Conference of KDU at: General Sir John Kotelawala Defence University, 47

8. Cooray T, Wei Y, Zhong H, Zheng L, Weragoda SK, Weerasooriya R (2019) Assessment of groundwater quality in CKDu Affected areas of Sri Lanka: Implications for drinking water treatment. International Journal of Environmental Research Public Health, 16(10). https://doi.org/10.3390/ijerph16101698

9. De La Mora-Orozco C, Flores-Lopez H, Rubio-Arias H, Chavez-Duran A, Ochoa-Rivero J (2017) Developing a Water Quality Index (WQI) for an Irrigation Dam. International Journal of Environmental Research and Public Health, 14(5), 439. MDPI AG. Retrieved from http://dx.doi.org/10.3390/ijerph14050439

10. Edirisinghe EANV, Karunarathne GRR, Samarakoon ASMNB, Pitawala HMTGA, Dharmagunawardhane HA, Tilakarathna IANDP (2016) Assessing causes of quality deterioration of groundwater in Puttalam, Sri Lanka, using isotope and hydrochemical tools. Isot Environ Health Stud 52(4-5):513-528. https://doi.org/10.1080/10256016.2015.1127918

11. Eltarabily MG, Moghazy HEM (2021) GIS-based evaluation and statistical determination of groundwater geochemistry for potential irrigation use in El Moghra, Egypt. Environ Monit Assess 193(5):306. https://doi.org/10.1007/s10661-021-09058-2

12. Farzaneh G, Khorasani N, Ghodousi J, Panahi M (2021) Assessment of Surface and Groundwater Resources Quality Close to Municipal Solid Waste Landfill Using Multiple Indicators and Multivariate 
Statistical Methods. International Journal of Environmental Research 15(2):383-394.

https://doi.org/10.1007/s41742-020-00307-9

13. Galhenage AC, Kumari EGSS, Kumara AMLU, Thalgaspitiya TWLR, Edirisinghe V, Vithanage M, Athapattu BCL (2021) Assessment of Groundwater Quality for Drinking Water from Deep Confined Aquifer in Wanathawilluwa. Lecture Notes in Civil Engineering, 94, 503-516. https://doi.org/10.1007/978-981-15-7222-7_41

14. Gitau MW, Chen J, Ma Z (2016) Water Quality Indices as Tools for Decision Making and Management. Water Resour Manage 30(8):2591-2610

15. Gnanachandrasamy G, Ramkumar T, Venkatramanan S (2015) Accessing groundwater quality in lower part of Nagapattinam district, Southern India: using hydrogeochemistry and GIS interpolation techniques. Appl Water Sci 5(1):39-55. https://doi.org/10.1007/s13201-014-0172-z

16. Gopalakrishnan T, Kumar L, Mikunthan T (2020) Assessment of spatial and temporal trend of groundwater salinity in Jaffna Peninsula and its link to paddy land abandonment. Sustainability (Switzerland), 12(9). https://doi.org/10.3390/su12093681

17. Gunaalan K, Ranagalage M, Gunarathna M, Kumari M, Vithanage M, Srivaratharasan T, Saravanan S, Warnasuriya TWS (2018) Application of Geospatial Techniques for Groundwater Quality and Availability Assessment: A Case Study in Jaffna Peninsula, Sri Lanka. ISPRS International Journal of Geo-Information 7(1):20. https://doi.org/10.3390/ijgi7010020

18. Gunarathna N, Amarasinghe A, Wijesundara S, Iddawela D, Wickramasinghe S (2021) Isolation, molecular characterization and phylogeny of Naegleria species in water bodies of North-Western Province, Sri Lanka. PLoS ONE 16(3 March):e0248510.

https://doi.org/10.1371/journal.pone.0248510

19. Hayzoun H, Garnier C, Durrieu G, Lenoble V, Le Poupon C, Angeletti B (2015) Organic carbon, and major and trace element dynamic and fate in a large river subjected to poorlyregulated urban and industrial pressures (Sebou River, Morocco). Science of the Total Environment, 502(2015), 296-308. https:// doi.org/10.1016/j.scitotenv.2014.09.014

20. Herath G, Ratnayake U (2007) Urban Groundwater Management Issues in Sri Lanka. Engineer: Journal of the Institution of Engineers, Sri Lanka, 40(4), 123. https://doi.org/10.4038/engineer.v40i4.7163

21. Herath HAS, Kubota K, Kawakami T, Nagasawa S, Motoyama A, Weragoda SK, Chaminda GGT, Yatigammana SK (2017) Potential risk of drinking water to human health in Sri Lanka. Environ Forensics 18(3):241-250. https://doi.org/10.1080/15275922.2017.1340364

22. IGES Freshwater Management Project (2007) the Study of the Management of Groundwater Resources in Sri Lanka. Sustainable Groundwater Management in Asian Cities2, 110-136. http://enviroscope.iges.or.jp/modules/envirolib/upload/981/attach/08_chapter3-5srilanka.pdf

23. International Water Management Project (2005) Planning Groundwater Use for Sustainable Rural Development Why must groundwater be managed better? Water Policy, 14 
24. Jain CK, Bandyopadhyay A, Bhadra A (2010) Assessment of ground water quality for drinking purpose, District Nainital, Uttarakhand, India. Environ Monit Assess 166(1-4):663-676. https://doi.org/10.1007/s10661-009-1031-5

25. Jayasena HAH, Chandrajith R, Dissanayake CB (2008) Hydrogeochemistry of the groundwater flow system in a crystalline terrain: A study from the Kurunegala district, Sri Lanka. Environ Geol 55(4):723-730. https://doi.org/10.1007/s00254-007-1024-z

26. Jehan S, Ullah I, Khan S, Muhammad S, Khattak SA, Khan T (2020) Evaluation of the Swat River, Northern Pakistan, water quality using multivariate statistical techniques and water quality index (WQI) model. Environ Sci Pollut Res 27(31):38545-38558. https://doi.org/10.1007/s11356-02009688-y

27. Kanga IS, Naimi M, Chikhaoui M (2020) Groundwater quality assessment using water quality index and geographic information system based in Sebou River Basin in the North-West region of Morocco. International Journal of Energy Water Resources 4(4):347-355. https://doi.org/10.1007/s42108020-00089-y

28. Khanoranga Khalid S (2019) An assessment of groundwater quality for irrigation and drinking purposes around brick kilns in three districts of Balochistan province, Pakistan, through water quality index and multivariate statistical approaches. J Geochem Explor 197:14-26

29. Marghade D, Malpe DB, Zade AB (2011) Geochemical characterization of groundwater from northeastern part of Nagpur urban, Central India. Environ Earth Sci 62(7):1419-1430. https://doi.org/10.1007/s12665-010-0627-y

30. Mikunthan T, De Silva CS (2008) Vulnerability Assessment for Shallow Aquifers Using Chemical Quality of Groundwater: A Case Study from Thirunelvely and Kondavil in Jaffna District. Tropical Agricultural Research 20:303-312

31. Mikunthan T, De Silva CS (2010) Sources of extent of groundwater pollution in shallow aquifer: A case study from Jaffna District in Sri Lanka. Third International Conference on Hydrology and Watershed Management in India, 41-48

32. Mukherjee I, Singh UK (2018) Groundwater Fluoride Contamination, Probable Release, and Containment Mechanisms: a Review on Indian Context. Environmental Geochemistry and Health

33. Narsimha A, Sudarshan V (2017) Contamination of fluoride in groundwater and its effect on human health: a case study in hard rock aquifers of Siddipet, Telangana State, India. Appl Water Sci 7(5):2501-2512. https://doi.org/10.1007/s13201-016-0441-0

34. Nihalani S, Meeruty A (2020) Water quality index evaluation for major rivers in Gujarat. Environ Sci Pollut Res, 1-9. https://doi.org/10.1007/s11356-020-10509-5

35. Pant BR (2011) Ground water quality in the Kathmandu valley of Nepal. Environ Monit Assess 178(1-4):477-485. https://doi.org/10.1007/s10661-010-1706-y

36. Premalal WAV, Jayewardene DT (2015) Effect of Low pH of Groundwater in Rathupaswala Area, Sri Lanka: A Case Study. publication/272175683_Effect_of_Low_pH_of_ 
Groundwater_in_Rathupaswala_Area_Sri_Lanka_A_Case_Study, pp 8-10.

https://www.researchgate.net/

37. Rabeiy RES (2018) Assessment and modeling of groundwater quality using WQI and GIS in Upper Egypt area. Environ Sci Pollut Res 25(31):30808-30817. https://doi.org/10.1007/s11356-017-86171

38. Rajasooriyar LD, Boelee E, Prado MCCM, Hiscock KM (2013) Mapping the potential human health implications of groundwater pollution in southern Sri Lanka. Water Resources Rural Development 12:27-42. https://doi.org/10.1016/j.wrr.2013.10.002

39. Rajmohan N (2021) Application of water quality index and chemometric methods on contamination assessment in the shallow aquifer, Ganges River basin, India. Environ Sci Pollut Res 28(18):2324323257. https://doi.org/10.1007/s11356-020-12270-1

40. Ramakrishnaiah CR, Sadashivaiah C, Ranganna G (2009) Assessment of water quality index for the groundwater in Tumkur taluk, Karnataka state, India. E J Chem 6(2):523-530

41. Sadat-Noori SM, Ebrahimi K, Liaghat AM (2013) Groundwater quality assessment using the Water Quality Index and GIS in Saveh-Nobaran aquifer, Iran. Environmental Earth Sciences, 71(2014), 3827-3843. https://doi.org/10.1007/s12665-013-2770-8.DOI10.1007/s12665-013-2770-8

42. Samanmali Matharaarachchi, Ranjana UK, Piyadasa D Wickramasinghe (2014) Groundwater quality variation in kalpitiya peninsula -Sri Lanka. SAITM Research Symposium on Engineering Advancements 2014 (SAITM - RSEA 2014)

43. Sampath GRA, Hewawasam ALT, Dias P (2011) Assessment of Groundwater Quality Status in Puttalam and Chillaw Area to Demonstrate its Suitability. as a Source of Potable Water

44. Şener Ş, Varol S, Şener E (2021) Evaluation of sustainable groundwater utilization using index methods (WQI and IWQI), multivariate analysis, and GIS: the case of Akşehir District (Konya/Turkey). Environ Sci Pollut Res, 1-20. https://doi.org/10.1007/s11356-021-14106-y

45. Singh S, Ghosh NC, Krishan G, Kumar S, Gurjar S, Sharma MK (2019) Development of indices for surface and ground water quality assessment and characterization for Indian conditions. Environ Monit Assess 191(3):1-20. https://doi.org/10.1007/s10661-019-7276-8

46. Tian Y, Jiang Y, Liu Q, Dong M, Xu D, Liu Y (2019) Using a water quality index to assess the water quality of the upper and middle streams of the Luanhe River, northern China. Sci Total Environ, 667(219), 142-151. https://doi. org/10.1016/j.scitotenv.2019.02.356

47. Tiwari AK, De Maio M, Amanzio G (2017) Evaluation of Metal Contamination in the Groundwater of the Aosta Valley Region, Italy. International Journal of Environmental Research 11(3):291-300. https://doi.org/10.1007/s41742-017-0027-1

48. United Nations Environment Programme (2018) Progress on Ambient Water Quality: Piloting the monitoring methodology and initial fndings for SDG 6 indicator 6.3.2. https://www.unwater.org/publi cations/progress-on-ambient-water-quality-632/

49. United Nations (2019) Leaving no one behind. https://unesdoc.unesc o.org/ark:/48223/pf0000367306 
50. Vaiphei SP, Kurakalva RM, Sahadevan DK (2020) Water quality index and GIS-based technique for assessment of groundwater quality in Wanaparthy watershed, Telangana, India. Environ Sci Pollut Res 27(36):45041-45062. https://doi.org/10.1007/s11356-020-10345-7

51. Villholth KG, Rajasooriyar LD (2010) Groundwater Resources and Management Challenges in Sri Lanka-an Overview. Water Resour Manage 24(8):1489-1513. https://doi.org/10.1007/s11269-0099510-6

52. Wang X, Zhang F (2018) Multi-scale analysis of the relationship between landscape patterns and a water quality index (WQI) based on a stepwise linear regression (SLR) and geographically weighted regression (GWR) in the Ebinur Lake oasis. Environ Sci Pollut Res 25(7):7033-7048. https://doi.org/10.1007/s11356-017-1041-8

53. WHO (2017) Guidelines for drinking-water quality. In: Incorporating 1st Addendum. fourth ed. World Health Organization, Geneva

54. Wickramasinghe BNB, Jayasena HAH, Perera KVGS, Rajapakse RRGR (2021) Assessment of hydrogeological scenario in a cross-section from Anamaduwa to Kalpitiya in Northwest Sri Lanka. Ceylon Journal of Science 50(1):83. https://doi.org/10.4038/cjs.v50i1.7850

55. Yang Y, Yin X, Yang Z (2016) Environmental flow management strategies based on the integration of water quantity and quality, a case study of the Baiyangdian Wetland China. Ecological Engineering. 96(2016), 150-161. https://doi.org/10.1016/j.ecole ng.2015.12.018

56. Yenugu SR, Vangala S, Badri S (2020) Monitoring of groundwater quality for drinking purposes using the WQI method and its health implications around inactive mines in Vemula-Vempalli region, Kadapa District, South India. Applied Water Science 10(8):202. https://doi.org/10.1007/s13201-02001284-2

57. Young SM, Pitawala A, Ishiga $H$ (2011) Factors controlling fluoride contents of groundwater in northcentral and northwestern Sri Lanka. Environ Earth Sci 63(6):1333-1342. https://doi.org/10.1007/s12665-010-0804-z

\section{Figures}




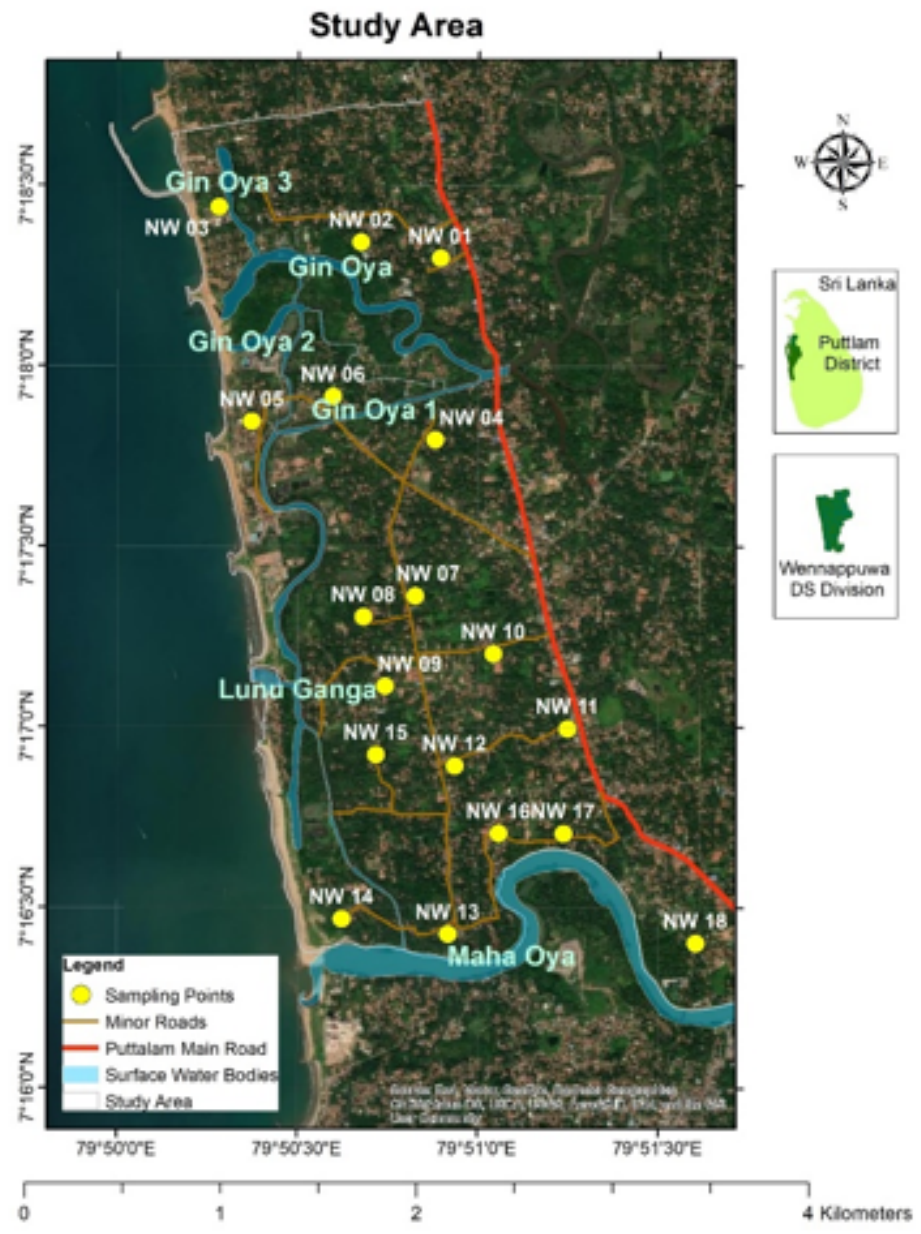

Figure 1

The selected case study region
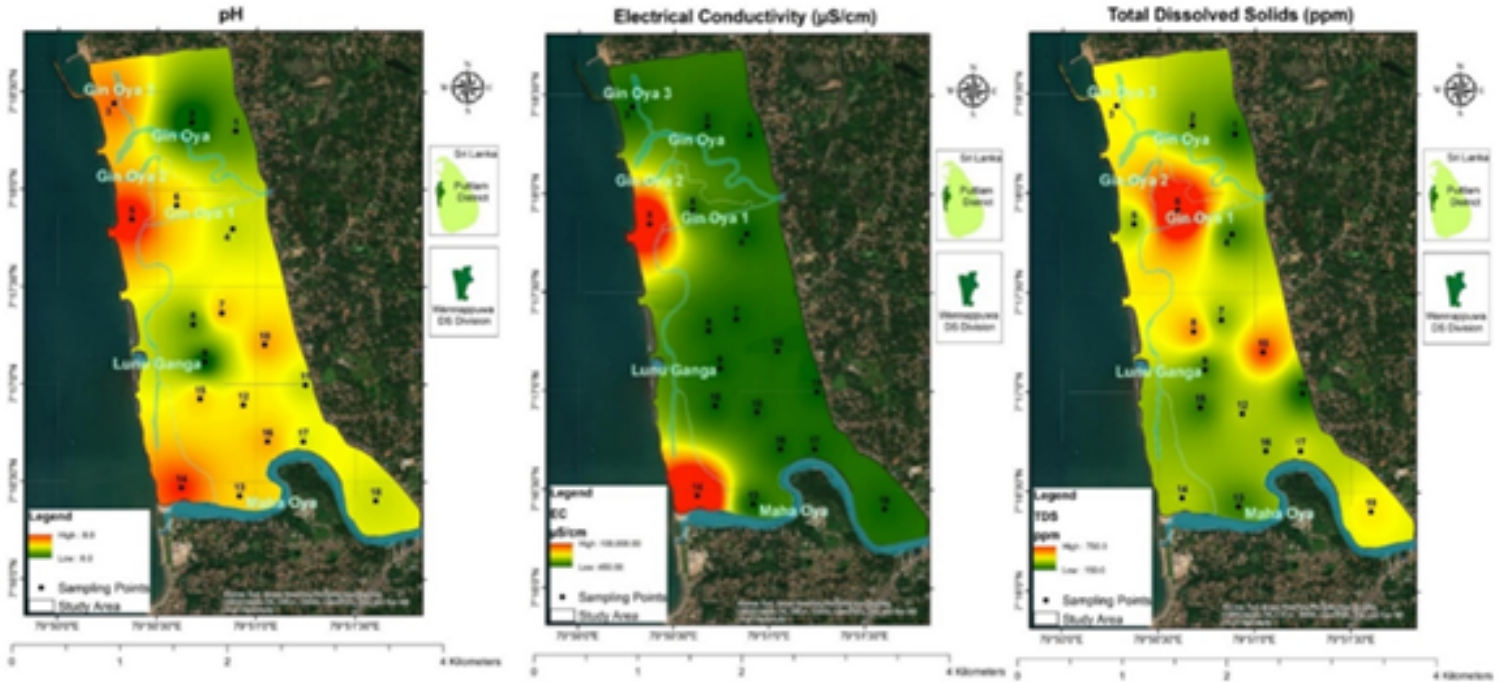

Figure 2 
Spatial distribution of Left: (a) pH Middle: (b) EC Right(c) TDS in the groundwater samples of the study area.



\section{Figure 3}

Spatial distribution of (a) Mg2+(b) Ca2+ in the groundwater samples of the study area. 

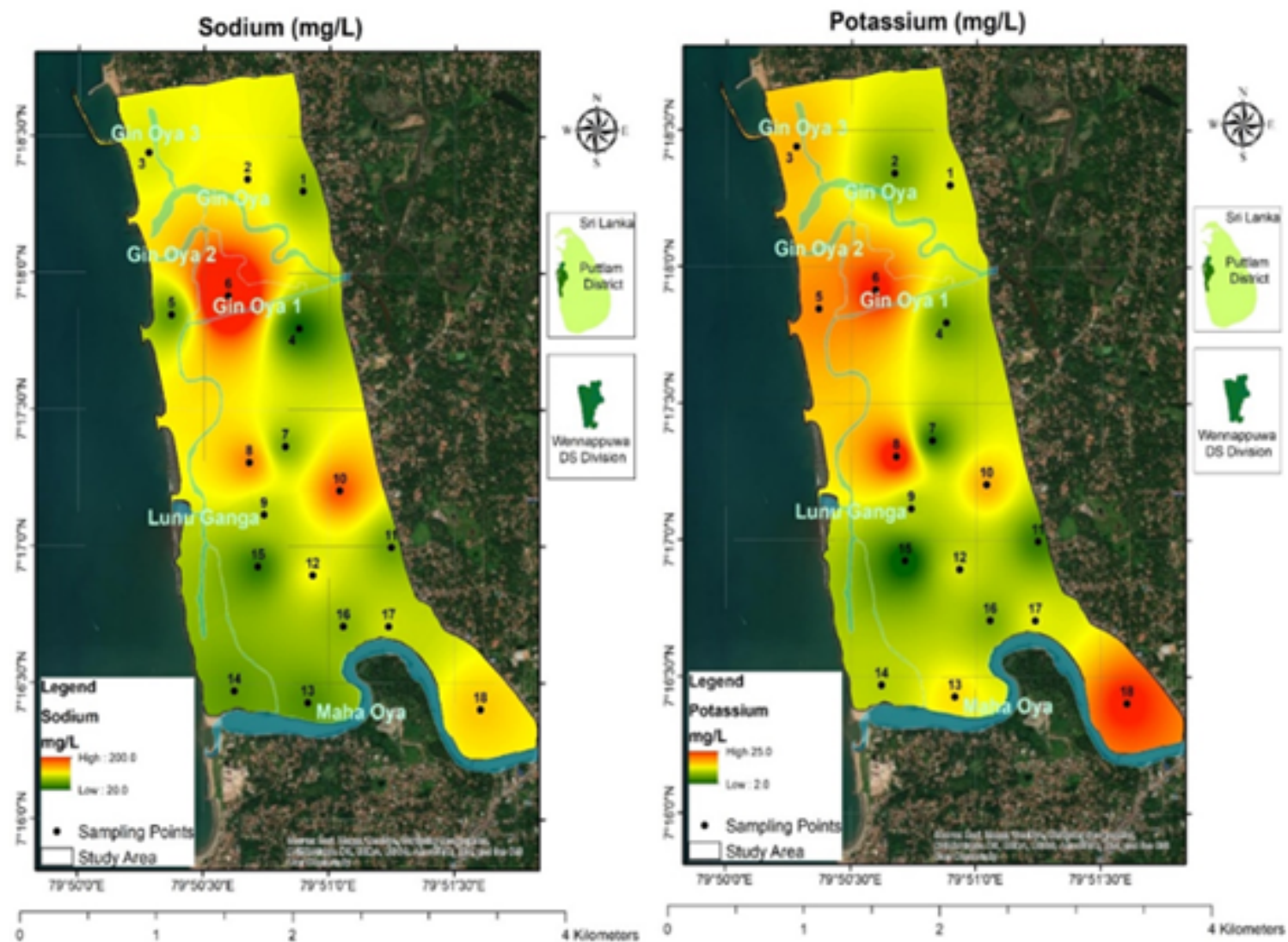

Figure 4

Spatial distribution of Left: (a) Na+ Right: (b) $\mathrm{K}+$ in the groundwater samples of the study area.


Figure 5

Spatial distribution of (a) $\mathrm{HCO}-(b) \mathrm{Cl}-$ (c) Turbidity in the groundwater samples of the study area. 


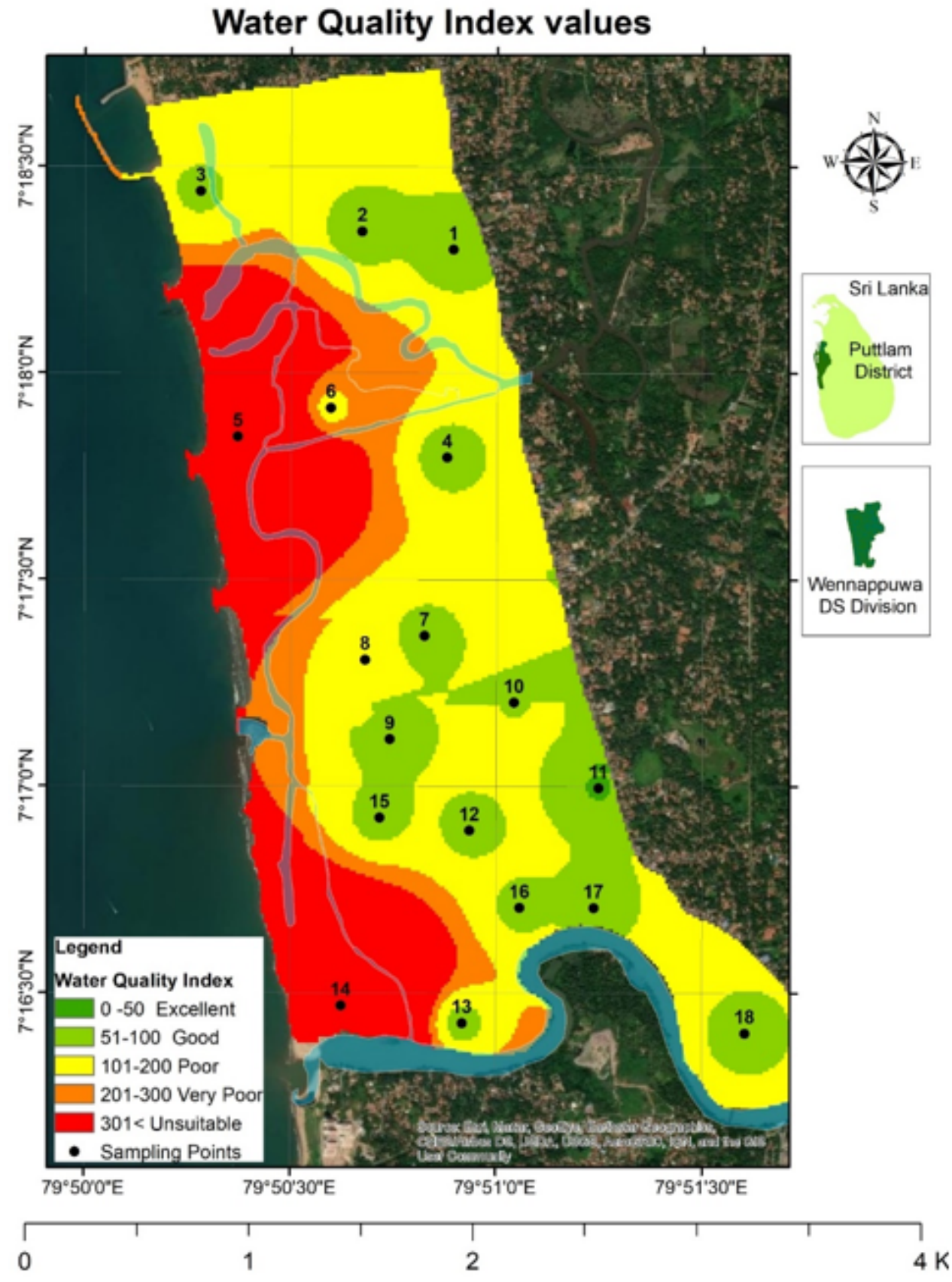

Figure 6

Spatial distribution map for the WQI of the study region 




\section{Figure 7}

Classification of groundwater quality index (GWQI) in the groundwater of the study area. 